\title{
SACRIFÍCIO DE ANIMAIS, PROTEÇÃO AMBIENTAL E LIBERDADE RELIGIOSA: UM DIÁLOGO POSSÍVEL?
}

\section{Carlos Augusto Lima Campos ${ }^{1}$}

\section{RESUMO}

O presente artigo se propõe a analisar em que medida a proteção à fauna pode ser imposta enquanto limite à prática de cultos religiosos nos quais ocorrem sacrifícios de animais. Advoga-se que a liberdade religiosa só tem sentido se compreendida como o direito não apenas de ter uma crença, mas de se determinar em razão dela, o que, evidentemente, não responde à problemática lançada, já no título, de maneira satisfatória. Neste diapasão, a pesquisa pretende identificar critérios minimamente seguros para uma interpretação constitucional adequada dos valores colidentes nos casos de sacrifícios de animais em rituais religiosos.

Palavras-chave: Bioética; Crueldade contra animais; Liberdade religiosa; Princípios Constitucionais; Proteção à fauna.

\section{ANIMAL SACRIFICE, ENVIRONMENTAL PROTECTION AND RELIGIOUS FREEDOM: THEY CAN TALK?}

\begin{abstract}
This research intends to analyze to what extent animal protection may be a limit to animal sacrifice rituals. It is proposed that the religious freedom only has meaning if understood as the right not only to have a belief, but to determine due to it, which, of course, does not respond satisfactorily to the issue launched already in the title. In this tuning fork, the research aims to identify ways minimally safe for a constitutional interpretation of values in colliding in cases of animal sacrifices in religious rituals.
\end{abstract}

Keywords: Bioethics; Cruelty to animals; Religious freedom; Constitutional Principles; Animal protection.

\section{Introdução}

O presente artigo se propões a analisar em que medida a proteção ambiental, notadamente à fauna, pode constituir um limite à prática de cultos religiosos em que se verifica a prática de sacrifícios de animais. A questão é complexa, mormente a partir do ponto de vista sustentado na presente pesquisa, segundo o qual a liberdade religiosa só tem sentido se compreendida como o direito não apenas de ter uma crença, mas de se determinar em razão dela. De outra forma, não haveria efetivamente um problema a ser resolvido. Como, por outro lado, nenhum direito ou valor pode ser compreendido em seu sentido absoluto, a

\footnotetext{
${ }^{1}$ Mestre em Ciências da Religião pela Universidade do Estado do Pará. Servidor Público junto ao Tribunal de Justiça do Estado do Pará. E-mail: prof.carloscampos@ gmail.com
} 
premissa acima, embora necessária à caracterização da emblemática como um problema constitucional, está longe de ser suficiente para a sua solução. Implica, portanto, compreender que a liberdade religiosa protege o direito de o cidadão se determinar em razão de uma crença religiosa e que tal fato não assegura, a priori, que todas as práticas religiosas, necessárias à sua autodeterminação, estarão protegidas pelo Direito.

O panorama se demonstra ainda mais polêmico se for considerado que a garantia constitucional da liberdade religiosa implica um compromisso do Estado em admitir e assegurar o respeito às mais variadas crenças e, consequentemente, às mais diferentes compreensões acerca da vida e de outros temas próprios do campo religioso, o que poderia eventualmente entrar em conflito com os conceitos "hegemônicos" socialmente verificados. Esse conflito potencial, assumido pelo próprio Estado, é o que torna complexas e sensíveis todas as questões relacionadas à liberdade religiosa, sobretudo quando envolvem as crenças que se demonstram minoritárias em determinadas sociedades.

Empreendidas tais considerações, pretende-se, aqui, identificar critérios minimamente seguros para uma interpretação constitucional adequada acerca dos valores envolvidos na temática atinente aos casos que envolvem sacrifícios de animais em rituais religiosos, à luz do ordenamento pátrio.

\section{Liberdade de Crença e de Culto: Harmonizando conceitos}

As liberdades de crença e de culto são asseguradas no inciso VI, do Artigo $5^{\circ}$, da atual Constituição da República Federativa Brasileira (CRFB/1988), que assim dispõe: “é inviolável a liberdade de consciência e de crença, sendo assegurado o livre exercício dos cultos religiosos e garantida, na forma da lei, a proteção aos locais de culto e a suas liturgias".

Genericamente, a liberdade de crença é compreendida pela doutrina brasileira como "a liberdade de escolha da religião, a liberdade de aderir a qualquer seita religiosa, a liberdade (ou o direito) de mudar de religião", assim como "a liberdade de não aderir a religião alguma, [...] a liberdade de descrença, a liberdade de ser ateu e de exprimir o agnosticismo" (SILVA, 2005, p. 249), ao passo que a liberdade de culto representaria a livre manifestação exterior da crença, pela prática de atos próprios da religião, ou seja, “a possibilidade de o indivíduo demonstrar externamente sua religião, podendo praticá-la não só nos templos como também no seu cotidiano, seja individualmente ou em grupo" (NAME, 2004, p. 80). Em outras 
palavras, "é como se a liberdade religiosa se dividisse em duas partes, a interna traduzia pela crença e a externa refletida pelo culto" (NAME, 2004, p. 80).

Como reflexo da ideia de que a liberdade de culto seria a exteriorização da liberdade de crença, tem-se que a primeira poderia sofrer limitações, ao passo que a segunda, por encontrar-se no âmbito interno do indivíduo, seria ilimitada. Ilustrativas, a esse respeito, as palavras de CASTRO (1935, p. 375) ao diferenciar a liberdade de crença (“direito que o indivíduo tem de filiar-se à religião que desejar ou não professar religião alguma; é ilimitada") da liberdade de culto ("garante a possibilidade de exteriorizar a fé; está sujeita às restrições legais").

Esses prismas, aliás, bastante difundidos, merecem - em caráter de urgência - algumas reflexões críticas. Compreender a liberdade de crença como uma manifestação interna do indivíduo implicaria reconhecer esse direito como uma espécie de liberdade interna, ou seja, uma "simples manifestação da vontade no mundo interior do homem" (SILVA, 2005, p. 231), e nada mais. Assim considerada, seria correto afirmar que essa seria uma liberdade ilimitada, como qualquer liberdade interna. Mas não é menos correto reconhecer que a liberdade religiosa assim compreendida não precisaria ser tutelada - como, mais uma vez, qualquer liberdade interna. De fato, a liberdade interna simplesmente não interessa ao Direito, pois, como bem reconhece José Afonso da Silva, "a questão fundamental [...] é saber se, feita a escolha, é possível determinar-se em função dela", ou seja, "se se têm condições objetivas para atuar no sentido da escolha feita", quando, então, "se põe a questão da liberdade externa" (SILVA, 2005, p. 231). É, portanto, a partir da ideia de liberdade externa, que "consiste na expressão externa do querer individual, e implica o afastamento de obstáculos ou de coações, de modo que o homem possa agir livremente" (SILVA, 2005, p. 231, 232), que se deve compreender a liberdade de crença.

Desse modo, deve-se assumir que a liberdade de crença é o direito de exprimir uma crença, e não o direito de ter uma crença (condição necessária, mas não suficiente à caracterização deste direito fundamental). E a crença protegida pela Constituição deve ser compreendida de forma ampla e aberta, assegurando aos cidadãos o direito de crer em conceitos e concepções religiosas que, como decidiu a Suprema Corte dos EUA, "podem parecer inacreditáveis, senão absurdas, para a maior parte das pessoas" ${ }^{2}$. Protege, assim, e igualmente, o direito de acreditar que Deus criou o mundo em seis dias - e descansou no

\footnotetext{
${ }^{2}$ United States v. Ballard - 322 U.S. 78 (1944).
} 
sétimo (judaísmo, cristianismo); que, após a morte, existe a reencarnação (espiritismo, hinduísmo, budismo); que um banho purificador promove uma "limpeza" de energias negativas (hinduísmo); que "a vida na Terra começou com uma deportação interplanetária em massa"3 (cientologia) ou, aceitando a provocação do jornalista Andrew Meuller, citado pelo ateu militante Richard Dawkins, que "o mundo tem a forma de um losango e que é carregado pelo cosmos nas pinças de duas enormes lagostas verdes chamadas Esmeralda e Keith" (DAWKINS, 2007, p. 82). Afinal, como enfatizou o juiz da Suprema Corte, William Douglas, no caso Ballard, "um homem tem o direito de acreditar em algo que não possa provar" e "se alguém puder ser preso pela decisão de um júri que, em ambiente hostil, considere sua doutrina falsa, pouco restará da liberdade religiosa" ${ }^{4}$.

Imperioso o reconhecimento de que o conteúdo da liberdade de crença compreende contornos mais amplos que o de simplesmente poder afirmar possuir um determinado credo (e assim exprimir uma crença), mas é este o seu núcleo de proteção. Seria como afirmar: é claro que a plena realização do direito à liberdade de crença depende não apenas do direito de exprimir a crença, mas também o direito a uma autodeterminação existencial a partir dela. Parece lógico que tal premissa impõe que o intérprete sempre considere haver uma "unidade essencial entre crença e conduta", pois, como recorda Jonatas Machado,

a liberdade religiosa não seria adequadamente tutelada se admitisse uma tão estrita como simplificadora bipolaridade entre crença (belief) e conduta (action), que resultasse numa generosa proteção da primeira e na desvalorização da segunda (MACHADO, 1996, p. 222)

No mesmo sentido, frisou Celso Ribeiro Bastos que "não há verdadeira liberdade de religião se não se reconhece o direito de livremente orientar-se de acordo com as posições religiosas estabelecidas" (BASTOS, 2001, p. 499).

Todavia, deve-se reconhecer que há distintos modos de se exprimir uma crença, os quais, inclusive, operam em diversos graus - alguns se limitando ao próprio crente, outros atingindo seus familiares, outros, ainda, atingindo terceiros que não compartilham da mesma crença -, de maneira que as restrições legítimas ao exercício deste direito fundamental serão

\footnotetext{
${ }^{3}$ A igreja invisível. Revista Época, 3 de abril de 2006, p. 71.

${ }^{4}$ United States v. Ballard - 322 U.S. 78 (1944).

${ }^{5} \mathrm{O}$ autor admite: “...compreende-se que as condutas coloquem mais problemas jurídicos do que as crenças em si”, mas ressalta: "no entanto, a construção dogmática de uma teoria das restrições do direito à liberdade religiosa com base na distinção entre umas e outras teria como consequência a descaracterização do fenômeno religioso e a subversão completa, ou o esvaziamento, do programa normativo que a Constituição lhe faz corresponder" (MACHADO, 1996, p. 222-223).
} 
mais comuns na medida em que envolvam uma conduta que ultrapasse a esfera meramente individual.

Compreendida, desse modo, a liberdade de crença, a ideia de que a liberdade de culto seria "a livre manifestação exterior da crença, pela prática de atos próprios da religião" deve ser ressignificada, já que esse conceito, de certa maneira, parece valer igualmente para ambas as liberdades. E, de fato, tanto a liberdade de crença como a liberdade de culto representam formas de manifestação exterior da religião professada, sendo ambas igualmente tuteladas pela Constituição, e ambas passíveis de sofrer restrições. A diferenciação entre essas liberdades decorrerá, portanto, da identificação de aspectos que permitam qualificar uma manifestação como cultual, o que em alguns casos poderá depender de pequenos detalhes. Nesse sentido, enquanto um cidadão orando (em silêncio) em uma praça pública estaria exercendo a liberdade de crença, um grupo de cidadãos orando da mesma forma e na mesma praça exerceriam a liberdade de culto. De todo modo, a diferença entre a liberdade de crença e a de culto perde importância na medida em que a Constituição de 1988 assegurou a inviolabilidade da primeira e o livre exercício da segunda, sem aquelas limitações relativas a ordem pública e bons costumes, que estiveram presentes em toda a história constitucional republicana.

Afastados esses conceitos vagos e indeterminados de ordem pública e, sobretudo, bons costumes, as limitações impostas à liberdade de culto deverão decorrer de uma interpretação sistemática do texto constitucional, na qual assumem destaque os princípios fundamentais da dignidade da pessoa humana, do pluralismo e da cidadania, que operam inclusive como um forte argumento em favor de uma concepção mais substantiva e mais inclusiva de democracia. Tais princípios, assim relacionados às liberdades de crença e de culto, permitem compreender esses direitos fundamentais como uma expressão da dignidade da pessoa ${ }^{6}$, sem qualquer juízo de valor sobre o conteúdo da crença professada, nem se admitindo qualquer ideia de verdade religiosa (em respeito ao Princípio da Pluralidade).

O conceito de dignidade da pessoa humana, em uma sociedade pluralista e em regime de democracia substancial e inclusiva, impõe ao intérprete, sobretudo em casos que envolvam a liberdade religiosa, um dever de empatia, de forma a permitir a compreensão, dentro deste conceito, de uma ideia de vida e dignidade eventualmente distinta daquela formulada pela

\footnotetext{
${ }^{6}$ Nesse sentido, defende Manoel Jorge e Silva Neto que, "sem dúvida, a opção religiosa está tão incorporada ao substrato de ser humano que o seu desrespeito provoca idêntico desacato à dignidade da pessoa humana". (SILVA NETO, 2006, p. 552).
} 
moral e cultura dominantes. Não se trata de uma relativização plena e absoluta do significado deste ou de outros princípios fundamentais, mas da compreensão de que o tratamento específico conferido à religião pela própria Constituição e a consideração das peculiaridades que o tema envolve (sentido da vida e da morte, prescrição de normas de conduta ética, etc.) permitem que se reconheça no mesmo Princípio da Dignidade da Pessoa Humana concepções distintas a respeito de seu sentido e alcance, condicionadas por leituras fundadas em crenças religiosas. Esta leitura mais empática da dignidade da pessoa humana, alicerçada justamente nos princípios fundamentais da cidadania e do pluralismo, é a que melhor se harmoniza com uma ideia de democracia inclusiva e substantiva.

Assim compreendida, a liberdade religiosa (que envolve tanto a liberdade de crença como a liberdade de culto) reforça a necessidade de, em casos que envolvam uma tensão entre normas estatais e condutas religiosas, buscar-se, quando possível, admitir exceções razoavelmente justificadas em favor destas, o que não significa que se deva reconhecer, $a$ priori, que a norma religiosa há de prevalecer sempre sobre a norma estatal, e nem mesmo que tal seria uma tendência. $\mathrm{O}$ conflito entre normas estatais e normas religiosas é usualmente resolvido em favor das primeiras, o que é até inevitável na maior parte dos casos. De todo modo, é possível sustentar, a partir da compreensão da liberdade religiosa interpretada à luz dos Princípios fundamentais da Dignidade da Pessoa Humana, da Cidadania e do Pluralismo, que a Constituição brasileira impõe que seja verificada a possibilidade de se conferir tratamentos excepcionais, em casos específicos, àqueles cidadãos que se encontram impedidos de exercer a sua religião por força de normas emanadas do Estado. Essa proposta, tímida até, se comparada às exigências feitas por cidadãos que professam religiões minoritárias no país, longe de figurar como uma aberração ao Estado de Direito, encontra respaldo até mesmo na jurisprudência da Suprema Corte dos EUA, de viés fortemente liberal em favor das condutas religiosas - ou ao menos assim usualmente identificada.

É válido destacar, por oportuno, que uma análise mais cautelosa de um determinado ordenamento jurídico permite visualizar que a laicidade adotada pelos diferentes Estados comporta matizes. Tal constatação deriva, obviamente, da tese de que o arquétipo de laicidade adotado por cada país deve ser coligido enquanto gradação do seu ordenamento jurídico constitucional. Equivale a compreender que são os preceitos constitucionais que vigoram em cada Estado que determinam os contornos da laicidade por ele adotada:

Uma primeira distinção a ser estabelecida é a de que Estado laico não se confunde com Estado antirreligioso. A experiência histórica tem demonstrado que tanto o 
Estado confessional quanto o ateísta atentam contra os ideais democráticos, porque não permitem ao ser humano o pleno desenvolvimento de suas potencialidades. $\mathrm{O}$ Estado confessional, quando entroniza determinada ideologia religiosa e reprime a exteriorização de outras crenças (ou descrenças), asfixia a realização das mais elementares aspirações do espírito humano. Do mesmo modo, o Estado ateísta, que substitui o conteúdo ideológico religioso por um conteúdo supostamente antirreligioso, não raramente marcado por características fortemente religiosas (por exemplo, culto ao Estado ou ao líder político). Ambos representam modelos que se servem do ser humano como mero instrumento para a realização de uma ideologia política ou religiosa e não como um fim em si mesmo. Neste sentido, um e outro são exemplos de desrespeito à dignidade humana. Algo muito preocupante atualmente é a tendência que se observa em alguns setores da imprensa para se opor ao direito de líderes religiosos expressarem suas opiniões a respeito de questões éticas relacionadas com alguma política pública. A Política governamental, com certeza, não deve ser orientada para atender os valores éticos defendidos por este ou aquele grupo religioso, mas não se pode negar o direito que os religiosos - como os líderes de outros segmentos da sociedade - têm de se manifestar sobre qualquer política pública, exercendo de modo pleno a cidadania. Por exemplo, é plenamente legítima a atitude dos bispos católicos de se insurgirem contra a distribuição de preservativos. Ao fazê-lo, estão tão somente expressando o ponto de vista religioso sobre o assunto. Posso não concordar com tal posicionamento, mas de modo algum me é lícito negar-lhes o direito a que o manifestem. Qualquer pessoa pode considerá-lo retrógrado e expor os motivos para que as políticas de saúde pública não o acolham. Porém, o argumento que muitas vezes tem sido utilizado - o de que eles deveriam ficar calados porque o Brasil é um país laico - nada mais é do que uma falácia autoritária. Democracia é convivência dos contrários. A tentativa de influenciar a política governamental é prerrogativa de qualquer grupo social, consectário inevitável da cidadania, não consistindo, em si, afronta à laicidade estatal (CAMPOS, 2010, p. 81-82).

Outro aspecto que deve ser visualizado, em cátedra, é o de que o Estado laico não é aquele absolutamente refratário a influências religiosas. Os protótipos de Estados laicos que adotaram políticas públicas que diretamente (ou não) desaguaram em movimentos capitaneados por líderes religiosos são inúmeros, e não raro a motivação religiosa constitui fator determinante para as lutas principiadas por determinados segmentos sociais, com o fito de viabilizar a adoção de políticas governamentais que melhorassem a vida da sociedade, coletivamente sopesada. Em particular, reputa-se o emblemático Martin Luther King Junior, onde ninguém, em sã consciência, poderia desconsiderar que muitas das políticas governamentais americanas foram fortemente influenciadas pelo Movimento dos Direitos Civis, liderado pelo pastor batista, a despeito das latentes motivações religiosas.

Então, se as políticas estatais não são diametralmente desprovidas de influência religiosa, e se o Estado laico não é sinônimo de antirreligioso (ou ateísta), qual a melhor hermenêutica para interpretá-lo, se é que tal questionamento pode ser encarado como "legítimo"?

$\mathrm{Na}$ verdade, laico nada mais é do que o caráter de neutralidade religiosa do Estado. O Estado laico é aquele que não privilegia nenhuma religião em particular e cuja 
política não é determinada por critérios religiosos. Significa dizer, ainda, que os Estados e as comunidades religiosas não sofrem interferências recíprocas no que diz respeito ao atendimento de suas finalidades institucionais. Vale lembrar, todavia, que interferência não se confunde com influência. Uma ilustração pode aclarar a distinção. Nada mais natural que dois jovens recém-casados tragam para o seu casamento a carga cultural recebida de seus pais. $\mathrm{O}$ modo pelo qual foram criados certamente contribui para sua visão de mundo e, de alguma maneira, influencia a vida do casal. Eventualmente, marido e mulher podem ouvir alguma sugestão dos seus pais sobre algum assunto em particular (a aquisição de um imóvel, por exemplo) e o jovem casal pode seguir ou não o conselho recebido. Isso pode ser rotulado como influência. Todavia, se a sogra da jovem esposa liga para a residência do casal e determina à cozinheira qual o cardápio diário a ser seguido, mesmo que motivada por preocupações com a saúde do seu filho, estamos diante de uma interferência e não mais de uma mera influência. Do mesmo modo, as políticas públicas não podem ser ditadas pelo pensamento religioso ou idealizadas para satisfazer este ou aquele grupo religioso, porque o que se busca numa comunidade política é a satisfação dos interesses de todo o grupo social, composto por cidadãos de todas as matizes ideológicas (religiosas ou não). Nada impede, entretanto, que grupos de pressão (religiosos ou não) postulem pela adoção de políticas públicas neste ou naquele sentido, conquanto o critério para a decisão estatal jamais deva ser determinado pelo pensamento religioso (TOURRANE, 1996, p. 14).

Nesse diapasão, e excetuados os sistemas jurídicos que adotam oficialmente um arcabouço ideológico antirreligioso (ou até ateísta) - e que não constituem propriamente modelos de Estado laico, mas alegorias de totalitarismo político), há dois modelos básicos de laicidade estatal. O primeiro é o que promove uma separação tendente a confinar a religião ao foro íntimo das pessoas, procurando afastá-la do espaço público. Este é, aparentemente, o modelo que vem paulatinamente sendo adotado nos países mais secularizados. O caso paradigmático é o da França, onde a religião tem sido gradualmente expulsa do espaço público, a ponto de o Parlamento francês ter aprovado uma lei (a 2004-228, de 15 de março de 2004) coibindo a utilização de símbolos e indumentárias que representem uma manifestação ostensiva de uma identidade religiosa, por parte de estudantes de instituições públicas de ensino.

O segundo modelo de Estado laico é o que, vislumbrando no fenômeno religioso um importante elemento de integração social, não almeja afastá-lo por completo da esfera política. Antes, chega a incentivar expressões de religiosidade no espaço público, chancelando-as de diversos modos, como, por exemplo, favorecendo o estabelecimento de capelanias em corporações militares.

Entre um modelo e outro, evidentemente, há diversos entretons, tendo em vista as especificidades de cada ordenamento jurídico nacional, bem como a tradição de cada povo. As dimensões da muralha que separa a comunidade política das organizações religiosas variam, assim, de Estado para Estado. Certamente há circunstâncias históricas específicas que 
explicam os porquês da preponderância, em um determinado sistema jurídico, de uma concepção mais próxima deste ou daquele padrão, circunstâncias estas que estão ligadas ao desenrolar do processo de secularização vivenciado por cada sociedade.

Importante salientar que a secularização - compreendida como o processo pelo qual a sociedade se afastou do controle da Igreja, de forma que a ciência, a educação, a arte e a política ficaram livres da conformidade com as hierarquias eclesiásticas, bem como do dogma teológico - enquanto fenômeno que alcança todo o mundo ocidental, manifesta-se de distintas maneiras nos diversos Estados, por razões igualmente diversas, dentre as quais se inclui até mesmo a concepção teológica sustentada pela expressão religiosa tida como majoritária, sendo válido ressaltar, exemplificativamente, que o processo de secularização em países de tradição calvinista não se dá na mesma celeridade que em países de tradição católica. Do mesmo modo, quando a analogia se perfaz, alegoricamente, entre países tradicionalmente muçulmanos e países tradicionalmente budistas. Outro aspecto singular, dentro de tais considerações, diz respeito à motivação cardinal da separação entre as organizações religiosas e o Estado, uma vez que

[...] as opiniões variam quanto ao que a doutrina constitucional da separação entre Igreja e Estado tem como intenção primeira. A intenção é proteger as Igrejas da interferência governamental ou proteger a política de grupos de pressão religiosos? Não parece desarrazoado que, embora o princípio da separação seja capaz de atender a ambos os interesses, dependendo das particularidades históricas de cada país que o adotou, tenha havido historicamente a precedência de uma intenção sobre a outra. Nos Estados Unidos, por exemplo, vê-se claramente que a intenção primeira dos constitucionalistas foi a de proteger as igrejas da interferência governamental, sobretudo para garantir proteção ao pluralismo religioso que marcou a história norteamericana desde os seus primórdios. Já na França, a intenção primeira - claramente perceptível na Declaração de Direitos do Homem e do Cidadão, de 1789 - foi a de proteger o Estado da interferência religiosa. Sem pretender superestimar tal dado, é plausível que os modelos de Estado laico que se desenvolvem em ambos os países tenham guardado alguma relação com a intenção inicial que determinou a adoção por cada ordenamento constitucional do princípio da separação entre Estado e confissões religiosas. A par disso, há também outro aspecto a ser considerado: em muitos países os movimentos sociais e políticos que levaram ao estabelecimento do princípio de separação entre a Igreja e o Estado, também agasalhavam representantes das confissões religiosas minoritárias, ora perseguidas, ora apenas toleradas pelo poder público. As confissões religiosas, a cujos integrantes não era conferida a plenitude dos direitos - não podiam, por exemplo, ser funcionários públicos - também se mobilizaram na luta pelo estabelecimento de um Estado laico, vendo aí a solução para que lhes fosse assegurada a cidadania plena. Se isso é verdade, não se pode dizer que necessariamente o processo de secularização levou à adoção do princípio da separação entre o Estado e as organizações religiosas. Muitas vezes, a adoção do princípio da separação resultou muito mais do interesse dos próprios grupos religiosos, receosos de que a organização política privilegiasse um determinado grupo em detrimento dos outros ou, pelo menos, de que esta adotasse uma postura invasiva em relação ao domínio religioso. Por isso, na evolução histórica de alguns países o princípio da separação pode não ter representado um efeito imediato do processo de secularização e, ao invés disso, ter até contribuído 
para a aceleração deste processo. O que cumpre salientar, entrementes, é que o princípio da separação é uma via de mão dupla: serve tanto para apartar a interferência esta tal na esfera religiosa quanto para refutar a interferência religiosa na esfera estatal (SMITH, 2001, p. 101).

Desse modo, revistos os argumentos e valores relacionados à interpretação da liberdade religiosa, e retomando a problemática relativa à prática de sacrifícios de animais em rituais religiosos, pode-se afirmar que restrições outrora consideradas constitucionais ( $a$ priori) a cultos religiosos (religiões de matriz africana, por exemplo) que envolvem sacrifício de animais, por simples violação à ordem pública ou aos bons costumes, passam a demandar, agora, uma análise mais detida a certas peculiaridades do caso concreto, e, da mesma forma como não há uma posição a priori pela inconstitucionalidade do ritual de sacrifício, também não há uma posição, prima facie, pela sua legitimidade.

\section{Sacrifício de animais em cultos religiosos de matriz africana}

A análise da constitucionalidade dos rituais de sacrifício de animais em cultos religiosos prescinde de qualquer consideração sobre o significado desses rituais para a religião. Isso porque a constitucionalidade ou inconstitucionalidade da prática simplesmente independe do significado que a religião lhe atribua, o que, aliás, só importa a quem compartilha a crença. Afinal, as crenças são protegidas independentemente do seu conteúdo. O que importa aqui, num primeiro momento, é reconhecer que sacrifícios e oferendas são elementos verificáveis, histórica e atualmente, em variadas confissões religiosas. Assiste razão a Fred Aflalo ao afirmar que:

Praticamente todas as religiões [...] praticam o sacrifício sangrento e a oferta de alimentos, explícita ou simbolicamente [...]. As pessoas desconhecem ou não percebem a realidade desses fatos de suas próprias religiões, horrorizando-se ante o "primitivismo" da prática nagô (AFLALO, 1996, p. 98).

Esse reconhecimento não é decisivo para a questão que se pretende analisar, mas é relevante juridicamente para se compreender que se está diante de uma prática própria do fenômeno religioso, o que se admite a partir de um conceito tipológico de religião, que parece o mais adequado para uma interpretação substancialmente democrática da liberdade religiosa ${ }^{7}$. Reconhecer que se trata de algo típico da religião é relevante, mas não é determinante. É necessário, mas não suficiente. A liberdade religiosa não assegura que uma conduta, apenas porque religiosamente motivada, terá tratamento excepcional em relação às

${ }^{7}$ Cf.: MACHADO, 1996; WEINGARTNER NETO, 2007; LEITE, 2008. 
normas estatais com as quais se encontra eventualmente em conflito - o que também não está totalmente excluído, dependendo a solução da controvérsia da análise de outros fatores relevantes ao caso.

Nesse sentido, destaca-se que a Constituição, após declarar que "todos têm direito ao meio ambiente ecologicamente equilibrado" (Art. 225, caput), dispõe que:

Art. $225, \S 1^{\circ}$, VII) para assegurar a efetividade desse direito, incumbe ao poder público [...] proteger a fauna e a flora, vedadas na forma da lei as práticas que coloquem em risco sua função ecológica, provoquem a extinção de espécies ou submetam os animais a crueldade.

Para o tópico em análise, a vedação relativa à extinção de espécies não parece passível de qualquer espécie de ponderação, sendo um óbice intransponível a qualquer prática de sacrifício animal, ainda que religiosamente motivada. Por outro lado, deve-se reconhecer que essa constatação é de interesse mais teórico do que prático, pois os animais envolvidos nos cultos de matriz africana, em regra, estão longe de se enquadrar na categoria de espécies em extinção.

A relação de animais a serem sacrificados varia de acordo com o orixá ao qual se dirige a oferenda, mas, grosso modo, é possível apontar bodes, cabras, carneiros, porcos, pombos, codornas, patos, frangos, galos e galinhas como os mais típicos dos rituais do candomblé e da umbanda ${ }^{8}$. Os animais relacionados, além de não serem espécies em extinção, são ainda utilizados para consumo, de acordo com o que é permitido pelo ordenamento jurídico brasileiro.

Esse é um dado relevante juridicamente na medida em que permite identificar um ethos da comunidade em relação aos animais em questão, e assim impede um tratamento discriminatório em relação a grupos religiosos minoritários que se valem desses mesmos animais em seus rituais de sacrifício. Esse, aliás, foi, de certo modo, o argumento de que se valeu a Suprema Corte dos EUA para declarar a inconstitucionalidade de um conjunto de normas da cidade de Hialeah (Flórida) que tornavam ilegal o sacrifício de qualquer animal. Um dos regulamentos deste conjunto normativo definia sacrifício como "matar desnecessariamente um animal em um ritual público ou privado ou cerimônia não com o propósito primário de consumo" (Regulamento 87-71), o que afetava diretamente os cultos da Igreja Lukumi Babalu Aye, praticante da Santeria (de matriz africana) e localizada naquela

\footnotetext{
${ }^{8} \mathrm{~A}$ análise da constitucionalidade dos sacrifícios de animais em rituais religiosos estará limitada aqui à relação de animais apontada nestes estudos: AFLALO, 1996, pp. 54-93; BASTIDE, 2001, p. 155; VOGEL et al, 2005, p. 55 e 113-118; PARÉS, 2007, p. 345. E o resultado da análise, condicionado ao uso apenas destes animais.
} 
cidade, e que moveu ação judicial contra o município, sob a alegação de que as normas violavam a liberdade religiosa ${ }^{9}$. Embora a cidade alegasse em sua defesa que se tratava de normas neutras, visando proteger os animais da crueldade e da matança desnecessária, o fato é que a legislação excluía praticamente todas as espécies de matança de animais, exceto as de sacrifício religioso. Isso foi decisivo para que a Suprema Corte, no caso Church of the Lukumi Babalu Aye vs. Hialeah City (julgado em 1993), decidisse pela inconstitucionalidade dessas normas municipais, que, como ressaltaram os ministros, não consideravam como matar desnecessariamente os animais as práticas de caça por lazer, a eutanásia em animais abandonados, e nem mesmo o uso de coelhos vivos para treinar cachorros de caça!

O importante em relação a esse caso não é exatamente o que foi decidido, mas por que foi decidido. Não se pode extrair desse julgado que a Suprema Corte tenha considerado inconstitucional uma lei de proteção aos animais apenas porque ela impedia o exercício dos cultos de religião de matriz africana. O que a Suprema Corte não admitiu foi a discriminação estabelecida pela comunidade local, que considerava lícitas diversas práticas que resultavam na morte de animais, exceto aquelas que integravam rituais de religião de matriz africana ${ }^{10}$. Por conseguinte, não seria possível afirmar qual seria o entendimento daquele Tribunal se houvesse efetivamente um entendimento comunitário coerente em relação à proteção da vida dos animais, e não uma mera discriminação voltada exclusivamente à religião de matriz africana $^{11}$.

Desse modo, verifica-se que, além do dado objetivo relacionado ao perigo de extinção, eventual proteção dedicada pela comunidade a determinadas espécies animais também pode operar como um limite ao sacrifício realizado em rituais religiosos. A ressalva pode ter caráter mais teórico do que prático, mas na relação de animais feita por AFLALO (p. 67) há menção ao papagaio como animal a ser sacrificado em oferenda a Ossaim, o que, em razão da especial proteção conferida pelo IBAMA àquela ave, tornaria $^{12}$ legítima a proibição de seu sacrifício em rituais religiosos.

\footnotetext{
${ }^{9}$ Church of Lukumi Babalu Aye, Inc. v. Hialeah - 508 U.S. 520 (1993).

${ }^{10}$ Como observou Gabriella Passalacqua, "a exigência quanto à existência de um propósito primário de consumo pretende até mesmo, mais adiante, isentar a matança Kosher - posto que o sacrifício nas religiões afro visa inicialmente à oferenda aos orixás ficando o consumo em segundo plano". (PASSALACQUA, 2010, p. 137).

${ }^{11}$ Gabriella Passalacqua cita alguns fatos que demonstram que "as leis criadas na Flórida tinham o nítido viés de hostilidade àquela religião". (PASSALACQUA, 2010, p. 136).

${ }^{12}$ A escolha do tempo verbal - futuro do pretérito - se deve ao fato de que não encontrei referência ao sacrifício de papagaios em nenhuma outra obra, não sendo possível afirmar se tal prática efetivamente ocorre.
} 
Se forem adotados como o universo de animais a serem sacrificados somente aqueles apontados nos estudos citados anteriormente, poder-se-ia constatar que os sacrifícios realizados nos cultos de religiões de matriz africana não envolvem espécies em extinção nem aquelas que gozam de proteção especial por parte do Poder Público - hipóteses que tornariam ilegítimas as práticas, ainda que religiosamente motivadas.

Ultrapassados esses pontos, a questão que restaria ser verificada refere-se à crueldade a que os animais estariam eventualmente submetidos. Em relação a esse ponto especificamente, algumas cautelas devem ser tomadas no processo de interpretação jurídica, considerando-se que se está diante de uma religião minoritária, que, ao menos no que tange aos rituais de sacrifício (efetivo, e não meramente simbólico) de animais, fogem à cultura e à moral dominantes na sociedade.

É justamente aqui que devem ser ressaltados os aspectos apontados no início deste ensaio a respeito da interpretação da liberdade religiosa na Constituição da República, a saber, a consideração dos valores constitucionais da democracia, do pluralismo, da cidadania e também da dignidade da pessoa humana, assim como a necessidade de uma empatia do intérprete ao lidar com questões relativas a minorias ${ }^{13}$. Neste ponto, a história brasileira coleciona fatos que apontam para uma dificuldade em lidar com a diferença que decorre de crenças não compartilhadas pela sociedade, ainda que esse conflito de valores seja por vezes mais aparente do que real, como visto no caso Church of the Lukumi Babalu Aye vs. Hialeah City, em que a suposta preocupação da comunidade com a matança desnecessária dos animais limitava-se aos sacrifícios religiosos. E nenhuma sociedade está livre dessa contradição - daí a necessária cautela quando da abordagem da temática.

Os estudos voltados às religiões de matriz africana, ao tratarem especificamente dos rituais de sacrifício de animais, não apontam práticas que poderiam ser caracterizadas como cruéis. É claro que essa avaliação, por razões óbvias, exclui do conceito de crueldade a morte do animal (que é implícita à ideia de sacrifício). Mas exclui também, e este é um ponto fundamental na interpretação da liberdade religiosa, qualquer juízo de valor sobre as razões que sustentam os rituais, que, como visto acima, só fazem sentido a quem professa a crença o que, aliás, vale para qualquer religião. O compromisso constitucional - frise-se - não é com o conteúdo da crença, mas com a liberdade para o seu exercício.

${ }^{13}$ Cf. MACHADO, 1996; COOKSON, 2001, p. 99. 
Em princípio, o sofrimento do animal objeto do sacrifício é o mesmo do animal abatido para consumo, não podendo ser este um argumento válido para um questionamento jurídico do rito religioso, salvo, é claro, se for demonstrado um tratamento cruel e de tortura maior no primeiro caso do que no segundo. A motivação, pelas razões acima expostas, também deve ser afastada na avaliação do caso. Tais considerações não afastam nem diminuem o valor da norma constitucional que veda as práticas que "submetam os animais à crueldade", norma a partir da qual, por exemplo, o Supremo Tribunal Federal (STF) considerou inconstitucional a manifestação cultural da Farra do Boi realizada no Estado de Santa Catarina (Recurso Extraordinário $n^{\circ}$ 1551). As razões da decisão foram pautadas nas práticas efetivamente adotadas contra os animais (práticas cujo controle, segundo ficou demonstrado no processo, estava escapando ao poder de polícia do Estado). É possível especular, a partir dos argumentos apresentados pelos ministros que formaram a maioria naquele julgado, que essa teria sido a decisão mesmo que a motivação da Farra do Boi fosse não cultural, mas religiosa. E, também nesse caso, a interpretação da Corte estaria correta.

\section{Conclusão}

O presente ensaio, em suas limitadas pretensões, buscou trazer as considerações necessárias à adequada interpretação constitucional da liberdade religiosa (aqui compreendida como liberdade de crença $e$ de culto) na análise dos casos envolvendo sacrifícios de animais praticados em cultos religiosos, mormente os de religiões de matriz africana. Verificou-se que, nesse campo, não existe uma proteção absoluta a essas práticas apenas porque religiosamente motivadas. Tratar-se-ia de uma leitura simplista e de todo modo equivocada da liberdade religiosa na ordem constitucional brasileira. Por outro lado, constatou-se também que a prática não pode ser condenada, a piori, sob alegação de violação à norma que proíbe práticas que submetam os animais à crueldade, devendo-se, para uma abordagem adequada da temática, considerar também outros valores constitucionais como a pluralidade, a democracia, a cidadania e a dignidade da pessoa humana. Derradeiramente, postulou-se a necessária empatia do intérprete para lidar com expressões de religiosidade que, embora minoritárias, gozam da mesma proteção que quaisquer outras. 
Para avigorar esse paradigma, observe-se uma passagem de uma crônica de Rubem Braga. Trata-se de um texto escrito na época em que o cronista desenvolveu certo interesse (ou curiosidade) pelas religiões de matriz africana. Dizia o autor estar passeando pelas ruas do Rio de Janeiro quando avistou uma casa grande, que não tinha jeito de "casa de família", e decidiu, então, entrar. Ali o cronista viu coisas extraordinárias, sobre as quais fez o seguinte relato:

\begin{abstract}
Havia, no fundo de uma ampla sala, armações de madeira, coloridas e iluminadas por pequenas lâmpadas elétricas e por algumas velas. Pelas paredes, em buracos apropriados, haviam sido espalhadas estatuetas malfeitas. Um homem com uma espécie de camisola preta e com um pano bordado de ouro nas costas dizia palavras estranhas, em uma língua incompreensível. A um gesto seu, mulheres e homens se ajoelharam murmurando coisas imperceptíveis. Depois apareceu um menino com uma camisola vermelha trazendo uma caçamba de onde saia fumaça cheirosa. Uma campainha fininha começou a tocar. Todo mundo ajoelhado abaixava a cabeça e batia no peito. $\mathrm{O}$ homem de camisolão preto bebeu um pouco de vinho e começou a meter na boca de cada velha que se ajoelhava em sua frente uma rodela branca. Em certo momento o menino de camisola saiu com uma bandeja. Pensei que ele fosse distribuir vinho, mas em vez disso recolhia níqueis e pratinhas. Depois umas senhoritas que estavam numa espécie de camarote começaram a cantar. Vi mulheres com véus na cabeça e fitinhas azuis no pescoço fazendo sinais estranhos (BRAGA, apud CARVALHO, 2007, p. 227).
\end{abstract}

Tratava-se de uma missa católica.

\title{
Referências
}

AFLALO, Fred. Candomblé: uma visão do mundo. 2. ed. São Paulo: Mandarim, 1996.

BASTIDE, Roger. O candomblé da Bahia: rito nagô. São Paulo: Companhia das Letras, 2001.

BASTOS, Celso Ribeiro. Direito de Recusa de Pacientes Submetidos a Tratamento Terapêutico às Transfusões de Sangue, por Razões Científicas e Convicções Religiosas. São Paulo: Revista dos Tribunais. Ano 90. v. 8, 2001.

CAMPOS, Carlos. Ensaios acerca da influência judaico-cristã nos institutos do direito de família. $2^{\mathrm{a}}$ edição. Belém: EDUFPA, 2010.

CARVALHO, Marco Antonio de. Rubem Braga: um cigano fazendeiro do ar. São Paulo: Globo, 2007. 
CASAMASSO, Marco Aurélio Lagreca. Política e religião: o Estado laico e a liberdade religiosa à luz do Constitucionalismo brasileiro. São Paulo: Tese de Doutorado - PUC-SP, 2006.

CASTRO, Araújo de. A Nova Constituição Brasileira. Livraria Editora Freitas Bastos, Rio de Janeiro, 1935.

COOKSON, Catharine. Regulating Religion: The courts and the free exercise clause. Oxford University Press, 2001.

DAWKINS, Richard. Deus: um delírio. (Tradução: Fernanda Ravagnani). São Paulo: Companhia das Letras, 2007.

LEITE, Fábio Carvalho. Estado e Religião no Brasil: a liberdade religiosa na Constituição de 1988. Rio de Janeiro: Tese de Doutorado - UERJ, 2008.

MACHADO, Jonatas Eduardo Mendes. Liberdade Religiosa numa Comunidade Constitucional Inclusiva - dos direitos da verdade aos direitos dos cidadãos, Coimbra: Coimbra Editora, 1996.

NAME, Paula Carmo. A liberdade de crença religiosa na Constituição Federal de 1988. Dissertação de mestrado em Direito Público (PUC-SP). São Paulo, 2004.

PARÉS, Luis Nicolau. A Formação do Candomblé: história e ritual da nação jeje na Bahia. 2. ed. Campinhas/SP: Editora Unicamp, 2007.

PASSALACQUA, Gabriella Palhares. Apartheid Religioso: a Suprema Corte dos EUA e o caso Church of the Lukumi Babalu Aye vs. Hialeah City. In: LEITE, Fábio Carvalho (org.). Cadernos do Departamento de Direito Constitucional - PUC-Rio, Série Monográfica: Laicidade e liberdade religiosa, v. 1, Núcleo de Estudos Constitucionais (NEC), 2010.

SILVA, José Afonso da. Curso de Direito Constitucional Positivo. 11. ed. São Paulo: Malheiros editores, 2005.

SILVA NETO, Manoel Jorge e. Curso de Direito Constitucional. 2. ed. Rio de Janeiro: Editora Lúmen Júris, 2006.

SMITH, Huston. Por que a religião é importante? O destino do espírito humano num tempo de descrença. Tradução de Cleusa M. Wosgrau e Euclides L. Calloni. $1^{a}$ edição. São Paulo: Cultrix, 2001.

TOURAINE, Alain. O que é democracia? 2a ed. Petrópolis: Vozes, 1996.

VOGEL, Arno; MELLO, Marco Antonio da Silva; BARROS, José Flávio Pessoa de. Galinha D'Angola: iniciação e identidade na cultura afro-brasileira. ed Rio de Janeiro: Pallas, 2005. 